\title{
IMMUNOPROPHYLAXIS OF STAPHYLOCOCCUS AUREUS MASTITIS IN DIARY COWS
}

VAKANJAC SLOBODANKA, PAVLOVIĆ M, PAVLOVIĆ V and OBRENOVIĆ SONJA

Faculty of Veterinary medicine, Belgrade

(Received 3. May 2007)

Mastitis in cows represents one of the most actual problems in intensive dairy production. The prevention of pathogen penetration in the udder, its colonization and reproduction impose the constant need for regular milk check-ups, and preventive and therapeutic measures. Staphylococcus aureus causes subclinical and clinical mastitis, which when in the acute form can originate difficult and malignant udder infections with granulomatous and necrotic changes. Chronic forms of Staphylococcal mastitis most often pass as subclinical cases. An efficient commercial vaccine has not been introduced yet, though the application of autochthonous vaccines in the prevention of mastitis can give satisfactory results.

In this study we have developed and applied an autochthonous vaccine prepared from $S$. aureus isolated from milk samples taken from an experimental farm, as well as from the referent capsular strain $S$. aureus. The vaccine was applied to experimental dairy cattle twice before calving in a dose of $5 \mathrm{~mL}$. It consisted of inactivated bacterial $S$. aureus JR3 cells in a quantity of $1 \times 10^{10} \mathrm{cfu} / \mathrm{mL}$ and $5 \mathrm{mg} \mathrm{SM}$ capsule of the strain S. aureus 2286. This vaccination of dairy cows has resulted in a significant decrease of subclinical and clinical manifested mastitis in the treated group, when compared to the vaccinated group of experimental animals.

Key words: mastitis, dairy cow, vaccine, S. aureus, immunoprophylaxis

\section{INTRODUCTION}

Mastitis in dairy cows is one of the most common problems in intensive diary production. It is the cause of striking economic losses, which in the last decade ranged from 12 to $80 \%$. The applied approaches to mastitis therapy have not given satisfactory results up to now, thus the problem of mastitis therapy is still present and actual. Local and parentheral antibiotic therapy, as well as adequate zooprophylactic and hygienic measures, proper milking and nutrition can give satisfactory results and decrease the incidence of mastitis. However, the problem is still present in intensive diary production, so new solutions with a modern 
approach have to be developed. Such solutions are reflected in the development of immunoprophylaxis and immunotherapy protocols.

Staphylococcus aureus udder infections in cows represent one of the major problems in intensive diary production. Of the total number of mastitis cases in dairy cows, those caused by S. aureus are represented in the range from $19 \%$ to $40 \%$ of all cases.

Published papers about vaccination of ruminants against causative mastitis agents describe limited positive results. In the '30ties it has been described that subcutaneous inoculation with viable $S$. aureus in sheep results in an increased resistance to experimentally induced mastitis (Munch-Peterson, 1938). During the '70ties vaccination against mastitis inducing antigens was based on polyvalent vaccines, which contained immunogenic staphylococcus, streptococcus and coliform bacterial strains, as well as exotoxins and endotoxins. Recent vaccines against Staphylococcus aureus induced mastitis contain inactivated S. aureus cells (Giraudo, 1997).

A number of papers indicate that in order to develop an inactivated $S$. aureus vaccine of a better quality alpha and beta toxoids, as well as capsular fragments of this pathogen have to be added (Calzolari, 1997; Watson, 1996; Leitner, 2003). Guidry (1994), Opdbeeck (1988) and Lee (2005) have described the preparation of the vaccine containing capsular antigens. Nordhaug (1994) states, as a new possibility the addition of protein $\mathrm{A}$ and fibronectin-binding protein as antigens in the stimulation of the active immune response. A completely new approach in the immunization of the udder was given by O'Brien (2001) who incorporeted the $S$. aureus lysate into biodegradable particles which have the function to stimulate antibody production and opsonization.

\section{MATERIAL AND METHODS}

Isolation and identification of S. Aureus vaccinal strains

Parallel to our outochtonous strains (JR1, JR2, JR3 and JR4) the referent capsular strain of $S$. aureus 2286 was studied and included in the vaccine preparation. This pathogen does not require specific growth media. It grows well on blood agar containing $5-10 \%$ blood and forms regular, round, slightly convex colonies (Quinn, 2002)

\section{Vaccine preparation}

The vaccine was prepared from the autochtonous strain JR3 which displayed the most typical biochemical characteristics of $S$. aureus and the referent capsulated strain 2286.

Vaccine constituent $A$.

A total of $5 \mathrm{~L}$ of Brain-Heart infusion was seeded with the isolated strain $S$. aureus JR3. The so inoculated medium was incubated at $37^{\circ} \mathrm{C}$ for $24 \mathrm{~h}$. After this incubation period $0.4 \% \mathrm{vol} / \mathrm{vol}$ formalin was added and incubation continued for further $24 \mathrm{~h}$. After the microorganism was inactivated by formalin the culture was centrifuged at $7000 \mathrm{rpm}$ at $4^{\circ} \mathrm{C}$ for $20 \mathrm{~min}$. The success of the inactivation process 
was checked out by repeating the incubation of a sample on blood agar. Lack of bacterial growth indicated that inactivation was successful.

After centrifugation the supernatant was discarded and the sediment resuspended in $0.9 \% \mathrm{NaCl}$ at $\mathrm{pH}$ 7.0. The resuspended sediment represents the first constituent $(A)$ of the vaccine.

Vaccine constituent B

The next step was the preparation of the referent capsular strain $S$. aureus 2286 which was seeded in $5 \mathrm{~L}$ of Brain-Heart infusion, as well. The so inoculated medium was incubated at $37^{\circ} \mathrm{C}$ for $24 \mathrm{~h}$ and thereafter centrifuged at $7000 \mathrm{rpm}$ at $4^{\circ} \mathrm{C}$ for $20 \mathrm{~min}$. The sediment was resuspended in saline and sterilized in an autoclave at $121^{\circ} \mathrm{C}$, thus the referent strain $S$. aureus 2286 was inactivated. Subsequently, the sample was centrifuged under the same conditions as strain JR3. The obtained supernatant represents the second constituent (B) of the vaccine, consisting of capsules of the strain $S$. aureus 2286 . In the supernatant $0.4 \% \mathrm{vol} / \mathrm{vol}$ formalin and $0.001 \% \mathrm{wt} / \mathrm{vol}$ of conservant timerasol were added.

The dose of the vaccine was $5 \mathrm{~mL} / \mathrm{cow}$, containing inactivated bacterial $S$. aureus JR3 cells in a quantity of $1 \times 10^{10} \mathrm{cfu} / \mathrm{mL}$ (constituent A) and $5 \mathrm{mg}$ SM capsule of strain S. aureus 2286 (constituent B).

By preparing the vaccine in the described manner a total of 135 doses $(5 \mathrm{~mL}$ each) was obtained.

Vaccine sterility and toxicity tests

To test for sterility the vaccine was seeded into 2 test tubes containing serum broth, 2 test tubes containing nutritious broth, Jansen's media with added starch and Jansen media with glucose added, nutritious oblique agar and blood agar. In none of the listed media aerobic or anaerobic bacterial growth was recorded. This proved that the vaccine was sterile.

Toxicity was tested for on a total of 10 white mice, 2 guinea pigs, 4 sheep and 5 pregnant cows. The vaccine in a dose of $5 \mathrm{~mL}$ was applied in two different ways i.e. there were two groups of 5 mice each. To one group the vaccine was applied intraperitoneally, and to the other group the route of application was subcutaneous. Mice to which the vaccine was applied intraperitoneally passed the biological test by not displaying any clinical signs. On post mortem examination there were no evident changes on the application site nor on parenchymatous organs. Mice to which the vaccine was applied subcutaneously behaved similarly, but showed on the application site small nodules.

Tests on guinea pigs and sheep did not indicate vaccine toxicity. The vaccine in a dose of $5 \mathrm{~mL}$ was applied subcutaneously in the neck region to pregnant cows, two months prior to calving. After vaccination there were no obvious changes in health status, feed intake, rumination or body temperature. On the application site a nodule the size of a nut was easy to palpate for a period of 10 - 20 days, after which it was reabsorbed. Thus, it was decided to administer the vaccine in two shots, $2.5 \mathrm{~mL}$ each, one on each side of the neck in the brachial region. 
Cytology tests

The number of milk somatic cells was studied under a light microscope. Milk samples for cytology tests were prepared in the following fashion: on a microscope glass slide $0.01 \mathrm{~mL}$ of milk was smeared over a surface of $1 \mathrm{~cm}^{2}$. To achieve this a piece of thin white cardboard marked with a $1 \mathrm{~cm} \times 1 \mathrm{~cm}$ square was placed under the glass slide. After drying-up the sample at room temperature for $24 \mathrm{~h}$, fats from the smear were removed with xylol, dried up and fixed in ethanol for 5 minutes. Thereafter the samples were dried and dyed with the previously prepared dye.

The number of somatic cells was determined by a formula that defines the microscope factor (MF) and the average cell count in 5 field views:

$$
\mathrm{MF}=100 / \mathrm{r}^{2} \pi \times n
$$

MF - microscope factor, $r$ - diameter of the eye field circle, $\pi$ - 3.14, $x$ - number of field viewings, $n$ - average number of leucocytes counted.

\section{Immune tests}

Tests for $S$. aureus antibodies in milk samples were carried out by commercial ELISA test (manufactured by VMRD, USA) in accordance to the manufacturer's instructions. Readings were performed at $620 \mathrm{~nm}$.

\section{Experiment}

In the experiment a total of 42 pregnant Holstein-Friesian cows, 4-5 years of age was included. Twenty-one cows were vaccinated two months before calving (start of dry period) and revaccinated one month prior to the expected date of delivery. The vaccine was administered subcutaneously in the neck region in a dose of $5 \mathrm{~mL}$. To the control group a placebo vaccine, consisting of $5 \mathrm{~mL}$ sterile saline was applied in the neck region, as well.

In order to determine the presence of $S$. aureus, milk samples were taken from all experimental cows before vaccination and after calving thereof in monthly intervals until first signs of clinical or subclinical mastitis were evident. The overall duration of the trial was 8 months. Samples were tested for specific antibodies, cell count and bacteria.

\section{RESULTS}

In an experimental dairy farm, which over a long period of time showed a high incidence of clinical and subclinical mastitis, the described protocol showed the following results:

Microbiological tests of milk samples from vaccinated and control dairy cows suffering from clinical or subclinical mastitis caused by S. aureus

Microbiological tests were carried out on milk samples from both groups starting prior to the dry term, which coincides with the first vaccination and thereof in regular monthly intervals after calving until first signs of mastitis in the experimental group were evident (Table 1). 
Acta Veterinaria (Beograd), Vol. 58, No. 2-3, 221-230, 2008.

Vakanjac Slobodanka et al.: Immunoprophylaxis of

Staphylococcus aureus mastitis in diary cows

Table 1. Incidence of clinical and subclinical mastitis caused by $S$. aureus

\begin{tabular}{|l|c|c|c|c|c|c|c|c|c|}
\hline & $\mathrm{n}$ & $\begin{array}{c}\text { S. } \\
\text { aureus } \\
\text { at the } \\
\text { start of } \\
\text { the trial }\end{array}$ & $\%$ & $\begin{array}{c}\text { S. } \\
\text { aureus } \\
\text { at the } \\
\text { end of } \\
\text { the trial }\end{array}$ & $\%$ & $\begin{array}{c}\text { Subclinical } \\
\text { mastitis }\end{array}$ & $\%$ & $\begin{array}{c}\text { Clinical } \\
\text { mastitis }\end{array}$ & $\%$ \\
\hline $\begin{array}{l}\text { Vaccinated } \\
\text { dairy cows }\end{array}$ & 21 & 7.00 & 33.30 & 3.00 & 14.20 & 3.00 & 14.20 & 0.00 & 0.00 \\
\hline $\begin{array}{l}\text { Control } \\
\text { group }\end{array}$ & 21 & 4.00 & 19.00 & 8.00 & 38.00 & 5.00 & 23.00 & 3.00 & 14.20 \\
\hline
\end{tabular}

$\mathrm{n}=$ Number of diary cows

At the beginning of the trial $S$. aureus was identified in $n=7$ (33.30\%) milk samples from vaccinated cows and in $n=4(19.00 \%)$ milk samples in the control group. After 8 months, at the end of the trial $S$. aureus was identified in $n=3$ $(14.20 \%)$ milk samples from vaccinated cows. At the same time a total of $n=8$ (38.00\%) milk samples from the unvaccinated group tested positive for $S$. aureus.

Subclinical mastitis was present in $n=5(23.00 \%)$ control cows, and in $n=3$ (14.20\%) vaccinated experimental cows. Clinical forms of mastitis were absent in the vaccinated group, while in the control group three cases $(14.20 \%)$ were confermed by microbiological testing.

\section{Somatic cell count and antibody levels}

Somatic cell count (SCC) in milk samples was carried out by counting the cells under light microscope. The level of specific $S$. aureus antibodies was performed by standard ELISA test (Staphylococcus Aureus Antibody Test Kit, VMRD). In order to provide a better insight into the obtained results the statistical measure "indexed number" was applied. This index is used in order to show the changes of a variable (or a group of variables) over a given time period, geographical location or some other relevant parameter. By calculating the indexed series (starting with $100 \%$ or $0 \%$ ) over a time period, the change, given as a percentage of the starting value, can be expressed referent to the starting point.

Maximal values for antibody levels in the control group at the start of the dry period were in the range from $0.606 \mathrm{OD}$ (optical density) to $1.410 \mathrm{OD}$. At the same time the minimal values, within the same group, ranged from 0.092 OD to 0.102 $\mathrm{OD}$. Within the vaccinated group maximal antibody values were from $0.957 \mathrm{OD}$ to $1.534 \mathrm{OD}$, and the minimal from $0.375 \mathrm{OD}$ to $0.512 \mathrm{OD}$.

The antibody level value in dairy calves before the dry period was $0.865 \pm$ $0.165 \mathrm{OD}$ in the control group and $0.974 \pm 0.148 \mathrm{OD}$ in the vaccinated group. After calving the values were $0.842 \pm 0.148$ and $1.162 \pm 0.165$, respectively. In the third month after calving the level of antibodies in the control group decreased to $0.299 \pm 0.165 \mathrm{OD}$ and did not change significantly until the end of the experiment.

Maximal values for milk SCC in the control group during the period of the trial ranged from $912.000 / \mathrm{mL}$ to $2.048 .000 / \mathrm{mL}$. In the same period the minimal 
reported values ranged from $27.200 / \mathrm{mL}$ to $78.000 / \mathrm{mL}$. During the same period the highest reported SCC values in the vaccinated group were within the range from $1.145 .600 / \mathrm{mL}$ to $2.240 .000 / \mathrm{mL}$ and the minimal from $21.333 / \mathrm{mL}$ to $97.600 / \mathrm{mL}$.

At the start of the trial the average SCC in $1 \mathrm{~mL}$ milk samples was $1.021 .550 \pm 248.429 / \mathrm{mL}$ in the control group and $776.350 \pm 297.312 / \mathrm{mL}$ in the experimental group.

After calving the average SCC was $799.500 \pm 248.429 / \mathrm{mL}$ in the control group and $853.600 \pm 297.312 / \mathrm{mL}$ in the experimental group of diary cows.

Three months after delivery the SCC in both groups was in the range from $300.000 / \mathrm{mL}$ to $600.000 / \mathrm{mL}$.

If the obtained values are indexed it becomes obvious that antibody levels from the starting value of $100 \%$ decreased to $33 \%$ and $54 \%$ in the control and vaccinated group, respectively. At the same time, SCC from the starting value of $100 \%$ decreased to $47 \%$ and $80 \%$ in the control and vaccinated group, respectively (Figure 1).

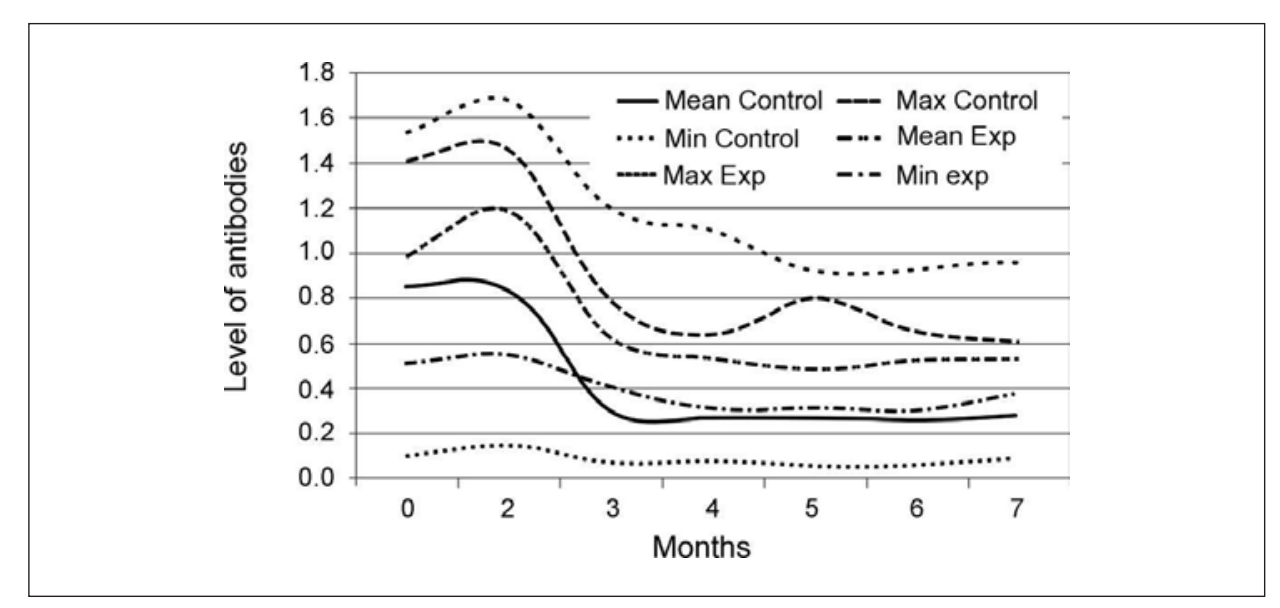

Figure 1. Level of antibodies (OD)

It is clear that the averages, minimal and maximal values for antibody concentrations in the vaccinated group are higher compared to the control group throughout the trial. In both groups there is a steady increase in antibody levels during the first two months, thereof the values decrease.

The indexed mean values of antibody levels in milk samples from vaccinated diary cows are higher throughout the duration of the trial (Figure 2). The diagram clearly shows a steady increase of antibody levels in milk samples during the first two months, followed by a gradual decrease until the third month of the trial when it reaches a steady state. The indexed antibody levels in the control group were $86 \%$ and $22 \%$ of the initial values in the control and vaccinated group, respectively. 


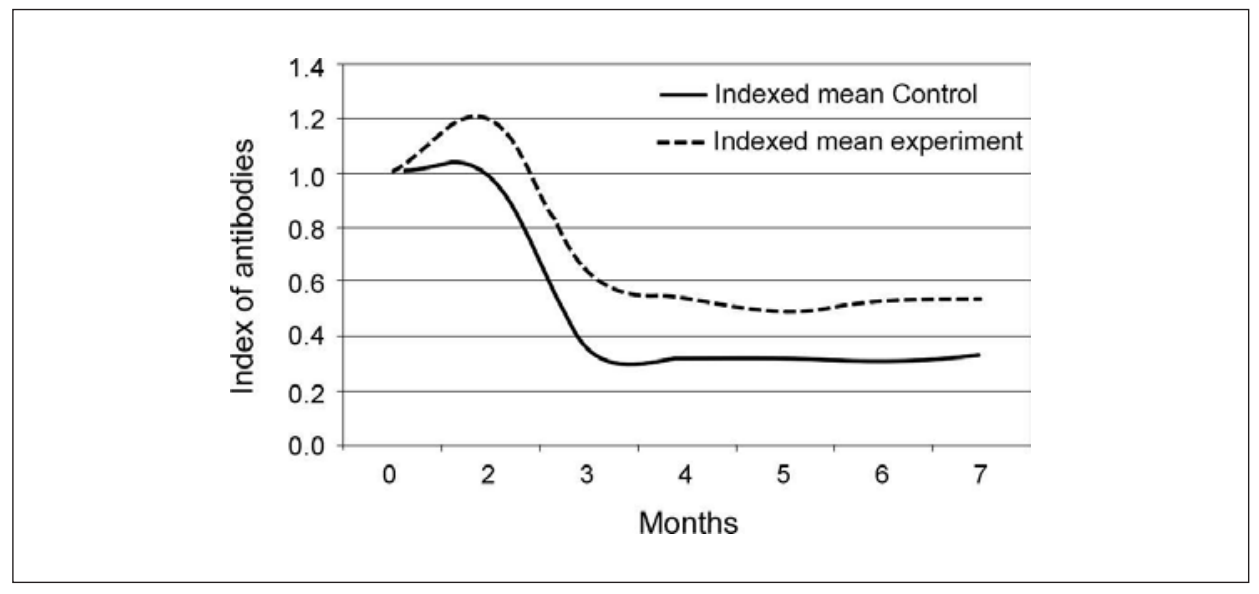

Figure 2. Indexed antibody values (\%)

\section{DISCUSSION}

Stojanovic et al. (2001) still consider mastitis to be one of the causes of greatest economic losses in diary farms. It is estimated that at least $40 \%$ of cows are infected by mastitis causing agents, but only $2-3 \%$ show signs of clinical forms of mastitis. Subclinical forms are often caused by S. agalactiae, Streptococcus spp., S. aureus and Staphylococcus spp. If only identified cases of subclinical mastitis caused by S. agalactie and $S$. aureus were observed a total from $16 \%$ (Nordhaug 1994, Edinger 2000) to $19 \%$ of observed dairy cows (Giraudo 1997) was affected. Our results have shown a higher incidence (33.30\%) of subclinical mastitis in diary cows.

Nordhaug (1994) described the incidence of subclinical mastitis caused by S. aureus to be present in $16 \%$ unvaccinated and $8.6 \%$ vaccinated dairy cows. Leitner et al. (2003) reported an extremely low incidence of cases of S. aureus subclinical mastitis, i.e. in $2.7 \%$ controls and among $1.3 \%$ vaccinated dairy cows. A much higher frequency of subclinical mastitis was reported by a number of authors. Watson (1996) reported $43 \%$ and $35.4 \%$ in control and vaccinated dairy cows, respectively. Similar results are published by Giraudo (1997) who identified a total of $40 \%$ of S. aureus subclinical mastitis in a herd of unvaccinated dairy cows and $15 \%$ among those that underwent prior vaccination.

Our results are close to those reported by Watson (1996) and Giraudo (1997). The experiment we have carried out has shown that a total of $23 \%$ of unvaccinated and $14.2 \%$ vaccinated dairy cows suffered from subclinical mastitis at the end of the experiment, relative to the $33 \%$ suffering at the very start of the research.

Based upon the obtained experimental results it can be concluded that the incidence of subclinical $S$. aureus mastitis could be lowered even more if a second vaccination was introduced four months after revaccination when antibody levels 
in the milk are at their lowest. By introducing this additional revaccination the existing decrease in antibody concentration could be avoided.

Edinger (2000) has described a very low incidence of clinical forms of S. aureus mastitis, which in the control group was present in 3.8\% cases and in $2.4 \%$ vaccinated dairy cows. Giraudo (1997) has established $12.5 \%$ clinical mastitis cases among the control cows and $2.5 \%$ cases within the studied population of vaccinated diary cows. An extremely high incidence of clinically manifest mastitis in diary cows (34.5\% in the control group and $16.3 \%$ in the vaccinated group) was described by Watson (1996) and Smith (2006). Nordhaug (1994) has established the presence of clinical mastitis in $6 \%$ control diary cows, while no cases were registered among the vaccinated animals.

Our results are close to those published by Nordhaug (1994), as among the vaccinated animals there were no cases of clinical $S$. aureus mastitis. At the same time in the unvaccinated control group a total of $14.2 \%$ displayed clear signs of mastitis. These results point out to the possibility of reducing the incidence of clinical forms of mastitis by immunoprophylaxis.

During involution of the mammary gland SCC increases up to $1.000 .000 / \mathrm{mL}$. However, before delivery this number decreases to physiological values (Seiff, 1932; Schalm, 1971; Nickerson, 1989). Our results have shown that the number of milk somatic cells at the beginning of the dry period was close to the published data i.e. $1.000 .000 / \mathrm{mL}$ and $800.000 / \mathrm{ml}$ in the control and treated group, respectively. According to Frerking (1961) at the beginning of lactation the SCC can increase up to $2.500 .000 / \mathrm{mL}$. In our trial, at the beginning of the experiment, the SCC was close to $800.000 / \mathrm{mL}$ in both groups. The obtained results are close to the findings of Giraudo (1997), Hoedmaker (1999), Edinger (2000).

When the number of somatic cells was indexed a minor decrease in SCC was determined within the experimental group when compared to the vaccinated group. When compared to the starting values the SCC fell within the control group down to $47 \%$, and to $80 \%$ in the vaccinated group. The higher count of milk somatic cells in the vaccinated group throughout the trial period can be accounted to the activation of cellular immunity as a response to the applied vaccine.

According to Stojic (2000) the concentration of IgG antibodies in milk is low (1-2 $\mathrm{mg} / \mathrm{mL}$ ) and primarily depends on vascular permeability of the blood/milk barrier. When during inflammation the integrity of the barrier is altered, the concentration of antibodies in milk increases to $50-80 \mathrm{mg} / \mathrm{mL}$. It is known that antibody levels in the dry period and in the colostrum are high, which is in agreement to our results. The average antibody concentration in the control and in the vaccinated group during the dry period was $0.851 \mathrm{OD}$ and $0.992 \mathrm{OD}$, respectively. Colostrum had an average antibody concentration in the control samples of $0.838 \mathrm{OD}$, while colostrum from the vaccinated group had an average antibody concentration which was much higher i.e. 1.187 OD.

High antibody levels in the vaccinated group at the start of the dry period are considered to be induced by the experimental vaccine. A high antibody titre in the colostrum of vaccinated cows has been described by Opdebeeck (1985), as well. 
After indexing the antibody levels a decrease in the values in the control group to $33 \%$ and in the vaccinated group to $54 \%$ from the starting value is evident. A significantly higher antibody concentration in the vaccinated group throughout the trial was determined by Opdebeeck (1985), Loeffer (1987), Nordhaug (1994), O' Brien (2000) and others.

Based upon our results it can be concluded that among diary cows that have been vaccinated twice during pregnancy with the tested vaccine, the incidence of subclinical and clinical mastitis was lower when compared to the control group.

Address for correspondence:

Dr Slobodanka Vakanjac

Department of obstetrics and $\mathrm{Al}$

Faculty of veterinary medicine

11000 Belgrade, Serbia

Bul. Oslobođenja 18

E-malil: vakanjac@vet.bg.ac.yu

\section{REFERENCES}

1. Calzolari A, Giraudo JA, Rampone H, Odierno L, Giraudo A, Frigerio C et al, 1997, Field Trial of a Vaccine Against Bovine Mastitis, 2. Evaluation in two Commercial Dairy Herds, J Dairy Sci 80, 854-8.

2. Edinger DB, Tenhagen BA, Baumgarrtner B, Heuwieser W, 2000, Efficacy of a herd specific vaccine against Staphylococcus aureus in dairy heifers, International Symposium on Immunology of Ruminant Mammary Gland, Stresa 2000.

3. Frerking $H$, 1961, Yur Festsellung von Enterstõrungen und Enteren-t zûndungen in Vorzugsmilhbetrie ben unter Verwendung geeigneter Laboratoriumsverfahren, Vet Med Diss, Hanover.

4. Giraudo JA, Calzolari A, Rampone H, Rampone A, Giraudo A, Bogni C, et al., 1997, Field Trial of a Vaccine Against Bovine Mastitis, 1. Evaluation in heihers, J Dairy Sci 80, 845-53.

5. Guidry AJ, O'Brien CN, Oliver SP, Dowlen HH, Douglass LW, 1994, Effect of whole Staphylococcus aureus and mode of immunization on bovine opsonizing antibodies, J Dairy Sci, 77, 10, 2965.

6. Hoedemaker M, Korff B, 1999, Untersuchungen zum Einsatz einer stallspezifischen Vakzine gegen Staphylococcus aureus in einem Milchviehbetrieb, Der praktische Tierarzt, collegium veterinarium XXIX, 68-71.

7. Lee JW, O'Brien CN, Guidry AJ,Paape MJ, Shafer-Weaver KA, Zhao X, 2005, Effect of a trivalent vaccine against Staphylococcus aureus mastitis lymphocyte subpopulations, antibody production, and neutrophil phagocytosis, Can J Vet Res, 69, 1, 11-8.

8. Leitnetr G, 2003, Development of a Staphylococcus aureus vaccine against mastitis in dairy cows, I Challenge trials, Vet Immunol Imunopathol, 30, 93, 1-2, 31-8.

9. Leitnetr G, 2003, Development of a Staphylococcus aureus vaccine against mastitis in dairy cows, II, Field trial, Vet Immunol Imunopathol, 20, 93, 3-4, 153-8.

10. Loeffer DA, Norcross NL, 1987, Use of enzyme-linked immunosorbent assay to measure bovine milk and serum antibodies to alpha toxin, beta toxin, and capsular antigens of Staphylococcus aureus, Vet immunol Immunopathol, 14, 145-56.

11. Munch-Peterson E, 1838, Bovine mastitis: survey of the literature to the end of 1935, Imperial Bureau of Animal Health, Review Series No 1, Weybridge,UK.

12. Nickerson SC, 1989, Imunological aspects of mammary involution, J Dairy Sci, 72, 6, 1665-78.

13. Nordhaug ML, Nesse LL, Norcross NL, Gudding R, 1994, A Field Trial with an Experimental Vaccine Against Staphylococcus aureus Mastitis in Cattle, 1, Clinical Parameters, J Dairy Sci, 77, 1, 1267-75. 
14. Nordhaug ML, Nesse LL, Norcross NL, Gudding R, 1994, A Field Trial with an Experimental Vaccine Against Staphylococcus aureus Mastitis in Cattle, 2, Antibody Response, J Dairy Sci, 77, 127684.

15. O'Brien CN, Gudry AJ, Fattom A, Shepherd S, Douglass LW, Westhoff DC, 2000, Production of antibodies to Staphylococcus aureus serotypes 5, 8, and 336 using poly (DL-lacide-coglycolide) microspheres, J Dairy Sci, 83 8, 1758-66.

16. O'Brien CN, Guidry AJ, Douglass LW, Westhoff DC, 2001, Immunization with Staphylococcus aureus lysate incorporated into microspheres, J Dairy Sci, 84, 8, 1791-9.

17. Opdebeeck A, 1988, Adhesion of Staphylococcus aurus and Escherichia coli to bovine Udder Epithelial Cell, Vet Microbiol, 16, 77-86.

18. Opdebeeck JP, Norcross NL, 1985, Antibodies in bovine serum and lactal secretions to capsular antigens of Staphylococcal aureus, Am J Vet Res, 46, 7, 1561.

19. Quinn PJ, 2002, Veterinary Microbiolgy and Microbial Disease, Blackwell Sciense Ltd, MPG books Ltd, Cornwall, UK.

20. Seiff E, 1932, Uberrden Zellgehalt chemisch einwandfreir und physiologisch verënderter, Milch Med Diss, Hanover.

21. Smith GW, Lyman RL, Anderson KL, 2006, Efficacy of vaccination and antimicrobial treatment to eliminate chronic intramammary Staphylococcus aureus infections in dairy cattle, J Am Vet Med Assoc, 228, 3, 422-5.

22. Schalm OW, 1971, Bovine mastitis, Philadelphia, USA.

23. Stojić V, Gvozdić D, 2000, Kvalitet kolostruma i stepen imunosti mladunčadi, Clinica veterinaria 2000, Drugo savetovanje iz kliničke patologije i terapija životinja, Budva.

24. Watson DL, McColl ML, Davies HI, 1996, Field trial of a staphylococcal mastitis vaccine in dairy herds: clinical, subclinical and microbiological assessments, AVJ, 447.

\title{
IMUNOPROFILAKSA MASTITISA KRAVA IZAZVANOG SA STAPHYLOCOCCUS AUREUS
}

\author{
VAKANJAC SLOBODANKA, PAVLOVIĆ M, PAVLOVIĆ V i OBRENOVIĆ SONJA
}

\section{SADRŽAJ}

Mastitisi krava predstavljaju jedan od najaktuelnijih problema u intenzivnoj proizvodnji mleka. Sprečavanje prodora patogenog uzročnika u mlečnu žlezdu, njegovo naseljavanje i razmnožavanje, nameću stalnu potrebu za redovnom kontrolom mleka, kao i preduzimanje preventivnih i terapijskih mera. Staphylococcus aureus izaziva subkliničke i kliničke forme mastitisa, koje mogu u akutnoj formi da izazovu teške, maligne mastitise u vidu granulomatoznih i nekrotičnih promena. Hronične forme stafilokoknog mastitisa uglavnom često prolaze kao subklinički oblici obolenja mlečne žlezde Još uvek nije pronađena komercijalna efikasna vakcina protiv mastitisa izazvanog $S$. aureus-om, ali primena autohtonih vakcina u preveniranju mastitisa može dati zadovoljavajuće rezultate. Koristili smo autohtonu vakcinu koju smo pripremili od $S$. aureus-a izolovanog iz mleka uzetog sa ogledne farme i referentnog kapsularnog soja $S$. aureus. Vakcina je dvokratno aplikovana oglednim kravama dva meseca pred telenje u dozi od $5 \mathrm{ml}$, a sastojala se od inaktivisanih bakterijskih ćelija S. aureus JR3 u količini od $1 \times 10^{10} \mathrm{cfu} / \mathrm{ml}$ i 5 mg SM kapsule soja $S$. aureus 2286. Ovaj način vakcinisanja krava protiv mastitisa izazvanog Staphylococcus aureus-om doveo je do smanjenja subkliničkih i kliničkih mastitisa u značajno manjem procentu u odnosu na kontrolnu grupu krava. 